\title{
A negative feedback between anthropogenic ozone pollution and enhanced ocean emissions of iodine
}

\author{
C. Prados-Roman ${ }^{1}$, C. A. Cuevas $^{1}$, R. P. Fernandez ${ }^{1, *}$, D. E. Kinnison ${ }^{2}$, J-F. Lamarque ${ }^{2}$, and A. Saiz-Lopez ${ }^{1}$ \\ ${ }^{1}$ Atmospheric Chemistry and Climate Group, Institute of Physical Chemistry Rocasolano (CSIC), Madrid, Spain \\ ${ }^{2}$ Atmospheric Division, NCAR, Boulder, CO, USA \\ *now at: National Scientific and Technical Research Council (CONICET), UTN-FR Mendoza/ICB-UNCuyo, \\ Mendoza, Argentina
}

Correspondence to: A. Saiz-Lopez (a.saiz@csic.es)

Received: 16 July 2014 - Published in Atmos. Chem. Phys. Discuss.: 27 August 2014

Revised: 4 February 2015 - Accepted: 5 February 2015 - Published: 27 February 2015

\begin{abstract}
Naturally emitted from the oceans, iodine compounds efficiently destroy atmospheric ozone and reduce its positive radiative forcing effects in the troposphere. Emissions of inorganic iodine have been experimentally shown to depend on the deposition to the oceans of tropospheric ozone, whose concentrations have significantly increased since 1850 as a result of human activities. A chemistry-climate model is used herein to quantify the current ocean emissions of inorganic iodine and assess the impact that the anthropogenic increase in tropospheric ozone has had on the natural cycle of iodine in the marine environment since pre-industrial times. Our results indicate that the human-driven enhancement of tropospheric ozone has doubled the oceanic inorganic iodine emissions following the reaction of ozone with iodide at the sea surface. The consequent build-up of atmospheric iodine, with maximum enhancements of up to $70 \%$ with respect to pre-industrial times in continental pollution outflow regions, has in turn accelerated the ozone chemical loss over the oceans with strong spatial patterns. We suggest that this ocean-atmosphere interaction represents a negative geochemical feedback loop by which current ocean emissions of iodine act as a natural buffer for ozone pollution and its radiative forcing in the global marine environment.
\end{abstract}

\section{Introduction}

Tropospheric ozone $\left(\mathrm{O}_{3}\right)$ is a short-lived greenhouse gas (GHG) with a positive radiative forcing (RF) of $0.4 \mathrm{~W} \mathrm{~m}^{-2}$ $\left(0.2-0.6 \mathrm{~W} \mathrm{~m}^{-2}\right.$ ) (Myhre et al., 2013). The main precur- sors of this GHG are $\mathrm{NO}_{\mathrm{x}}\left(\mathrm{NO}\right.$ and $\left.\mathrm{NO}_{2}\right)$, hydrocarbons, $\mathrm{CO}, \mathrm{CH}_{4}$ and stratospheric downward transport, whereas its main sinks include photodissociation, deposition and reactions with the chemical families of odd oxygen, hydrogen, nitrogen and halogens (Braseur and Solomon, 2005; Myhre et al., 2013).

About a decade ago iodine oxide was detected in the marine boundary layer (MBL) (Alicke et al., 1999). Since then, several studies have aimed at determining the source gases of iodine and their chemical pathways (see Saiz-Lopez et al., 2012a, and references therein). While emissions of very short-lived (VSL) organic source gases $\left(\mathrm{CH}_{3} \mathrm{I}, \mathrm{CH}_{2} \mathrm{I}_{2}\right.$, $\mathrm{CH}_{2} \mathrm{ICl}$ and $\mathrm{CH}_{2} \mathrm{IBr}$ ) have been observed in supersaturated waters (Carpenter et al., 2012), the existence of an abiotic ocean source of iodine has been directly and indirectly inferred throughout scattered field campaigns and 1-D model works (Read et al., 2008; Jones et al., 2010; Mahajan et al., 2010, 2012; Gómez Martín et al., 2013; Großman et al., 2013; Lawler et al., 2014). Very recently, laboratory studies have demonstrated the potential of the ocean to emit inorganic hypoiodous acid (HOI) and, to a lesser extent, molecular iodine $\left(\mathrm{I}_{2}\right)$ following the reaction of ozone with iodide at the sea surface (Carpenter et al., 2013; MacDonald et al., 2014). The oceanic emission of inorganic iodine source gases (ISG; i.e. HOI, $\mathrm{I}_{2}$ ) has been experimentally shown to depend on the deposition of tropospheric ozone to the oceans (estimated to be in the range of $200-350 \mathrm{Tg} \mathrm{O}_{3} \mathrm{yr}^{-1}$; Ganzeveld et al., 2009), wind speed and sea surface temperature (SST) (Garland et al., 1980; Carpenter et al., 2013; MacDonald et al., 2014). 
Given that anthropogenic activities have led to an increase of 20-55\% in tropospheric ozone since 1850 (Myhre et al., 2013) and that the current halogen-mediated troposphericozone loss in the tropical regions accounts for $-0.1 \mathrm{~W} \mathrm{~m}^{-2}$ of the radiative flux at the tropical tropopause (i.e. $\sim 1 / 3$ of the total tropospheric $\mathrm{O}_{3}$ RF; Saiz-Lopez et al., 2012b), this study aims at (i) assessing how the anthropogenic increase in tropospheric ozone has affected the abiotic oceanic emission of ISG and (ii) describing a geochemical feedback mechanism between ozone and iodine that mitigates the positive radiative forcing of tropospheric ozone in the global marine environment. In this work Sect. 2 provides details on the setup of the chemistry-climate model employed in this study, while the results for pairs of model runs for different periods of time are discussed in Sect. 3. The summary and conclusions are presented in Sect. 4.

\section{Methods}

The chemical simulations in this study were performed with the 3-D CAM-Chem chemistry-climate model (Community Atmospheric Model with Chemistry, version 4.0), included into the CESM framework (Community Earth System Model, version 1.1.1) (Lamarque et al., 2012). A summary of the model set-up and simulations used in this study are provided below, whereas a detailed description of the model as well as the iodine chemical scheme and reaction rates is described elsewhere (Lamarque et al., 2012; Ordóñez et al., 2012; Saiz-Lopez et al., 2014).

\subsection{Model set-up}

The model set-up used for all simulations considered a horizontal grid resolution of $1.9^{\circ}$ (latitude) $\times 2.5^{\circ}$ (longitude) and 26 hybrid vertical levels from the surface to approximately $40 \mathrm{~km}$ (Lamarque et al., 2012). In order to allow the stabilisation of the tropospheric conditions and to perform a direct chemical comparison between simulations representative of different time periods, all simulation schemes considered identical prescribed SST and sea-ice boundary conditions representative of the year 2000 (Rayner et al., 2003). Since model results are not representative of the meteorology of any specific year, annual averages are presented. In all cases, ocean and land masks were applied to the model streaming in order to compute the global absolute and relative averages presented here.

\subsection{Ocean iodine emissions}

The global emission inventory of CAM-Chem was updated by the inclusion of a state-of-the-art iodine and bromine photochemical mechanism, including natural oceanic sources of VSL bromo- and iodocarbons which have previously been validated (Ordóñez et al., 2012; Saiz-Lopez et al., 2012b). The current work focuses in particular on the emission of

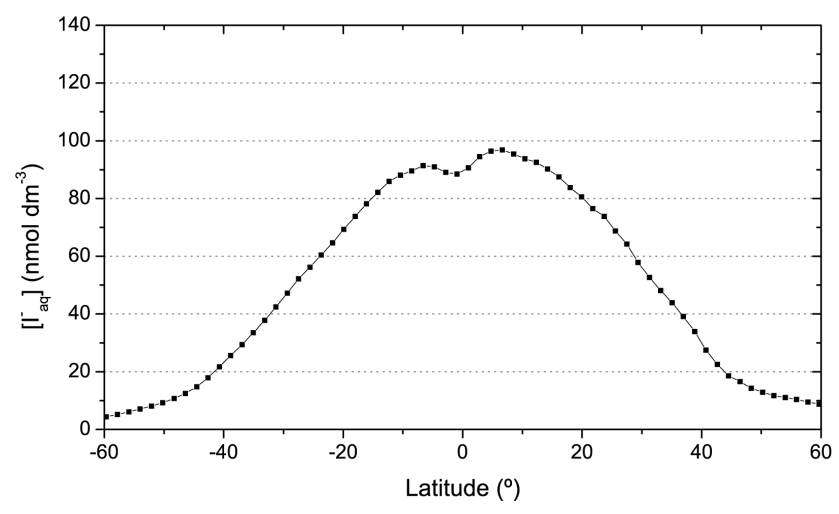

Figure 1. Modelled latitudinal variation of the zonal average sea surface iodide concentration, $\left[\mathrm{I}_{\mathrm{aq}}^{-}\right]$. Following Eq. (4), $\left[\mathrm{I}_{\mathrm{aq}}^{-}\right]$is modelled with CAM-Chem using SST as a proxy. Modelled iodide values fall within the range of $\left[\mathrm{I}_{\mathrm{aq}}^{-}\right]$open-ocean measurements reported by Chance et al. (2014), also reproducing the iodide gradient observed towards the Equator (see also Ganzeveld et al., 2009).

ISG emitted from the ocean after the oxidation of aqueous iodide by $\mathrm{O}_{3}$ deposited in the ocean (Garland et al., 1980) and the resulting emission of $\mathrm{HOI}$ and $\mathrm{I}_{2}$. This emission function was included in CAM-Chem following the parameterisation derived by Carpenter et al. (2013):

$\mathrm{ISG}=\operatorname{Flux}(\mathrm{HOI})+2 \times \operatorname{Flux}\left(\mathrm{I}_{2}\right)$,

where

$$
\begin{aligned}
\operatorname{Flux}(\mathrm{HOI}) & =\left[\mathrm{O}_{3}\right] \times\left(4.15 \times 10^{5} \times\left(\frac{\sqrt{\left[\mathrm{I}_{\mathrm{aq}}^{-}\right]}}{w}\right)\right. \\
& \left.-\left(\frac{20.6}{w}\right)-23600 \times \sqrt{\left[\mathrm{I}_{\mathrm{aq}}^{-}\right]}\right)
\end{aligned}
$$

$$
\begin{aligned}
\operatorname{Flux}\left(\mathrm{I}_{2}\right) & =\left[\mathrm{O}_{3}\right] \times\left[\mathrm{I}_{\mathrm{aq}}^{-}\right]^{1.3} \times\left(1.74 \times 10^{9}\right. \\
& \left.-\left(6.54 \times 10^{8} \times \ln w\right)\right)
\end{aligned}
$$

with $w$ being the wind speed $\left(\mathrm{m} \mathrm{s}^{-1}\right),\left[\mathrm{O}_{3}\right]$ the surface ozone mixing ratio $\left(\mathrm{nmol} \mathrm{mol}^{-1}\right)$ and $\left[\mathrm{I}_{\mathrm{aq}}^{-}\right]$the concentration of aqueous iodide $\left(\mathrm{mol} \mathrm{dm}^{-3}\right)$ (Carpenter et al., 2013). Based on the work of MacDonald et al. (2014), the sea surface temperature $(\mathrm{SST}, \mathrm{K})$ was used as a proxy for describing $\left[\mathrm{I}_{\mathrm{aq}}^{-}\right]$:

$\left[\mathrm{I}_{\mathrm{aq}}^{-}\right]=1.46 \times 10^{6} \times \exp \left(\frac{-9134}{\mathrm{SST}}\right)$.

Recently, the coincident study of Chance et al. (2014) has compiled the sparse measurements of sea surface iodide and has also concluded that SST is the best proxy to reproduce the geographical distribution of $\left[\mathrm{I}_{\mathrm{aq}}^{-}\right]$. In that work the authors estimated a slightly higher correlation coefficient between 


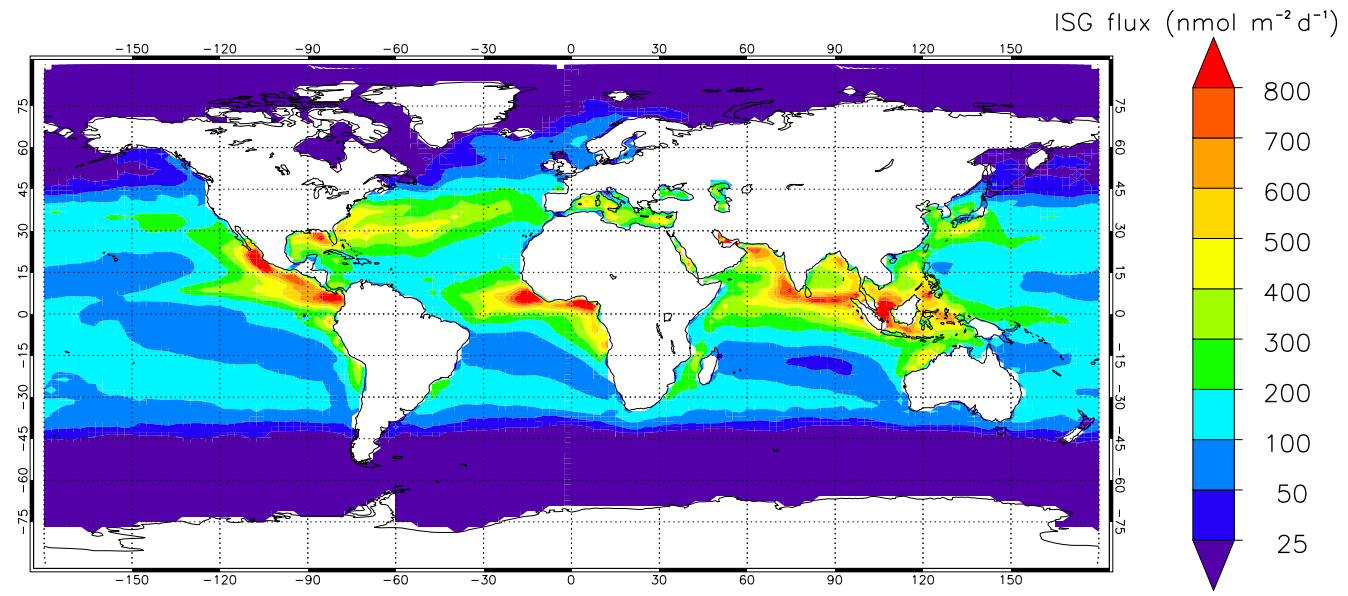

Figure 2. Modelled annual mean ocean flux of ISG. Following the laboratory work of Carpenter et al. (2013) and MacDonald et al. (2014), the parameterisation of the ISG flux given by Eqs. (1)-(4) was newly implemented in the global chemistry-climate model CAM-Chem.
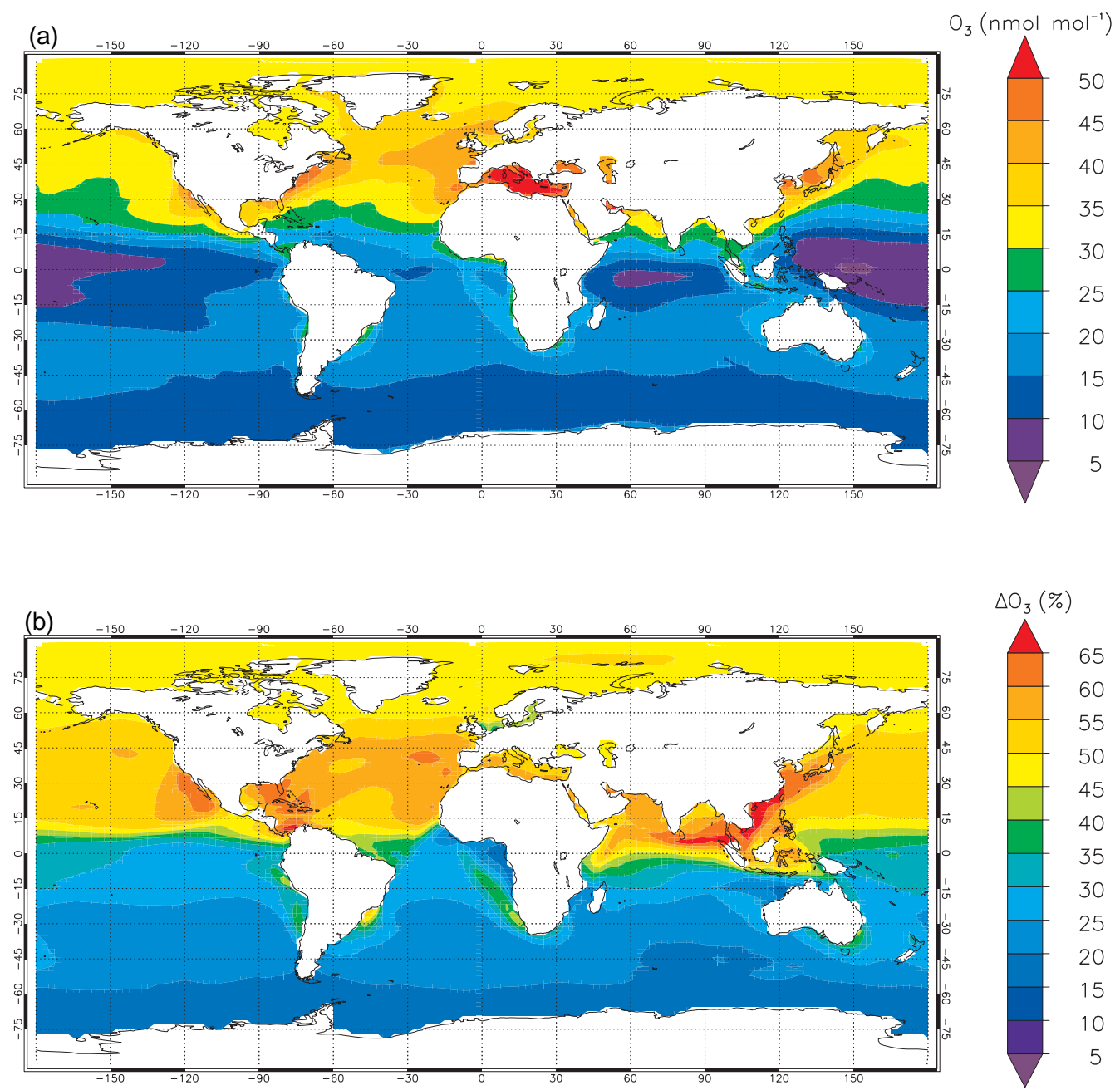

Figure 3. Modelled surface ozone in the marine environment: (a) present-day surface $\mathrm{O}_{3}$ mixing ratio; (b) relative change of surface $\mathrm{O}_{3}$ mixing ratio since pre-industrial times. As a result of the hemispheric gradient on the emissions of ozone precursors (Myhre et al., 2013), the increased ozone load in the Northern Hemisphere has doubled that of the Southern Hemisphere. 


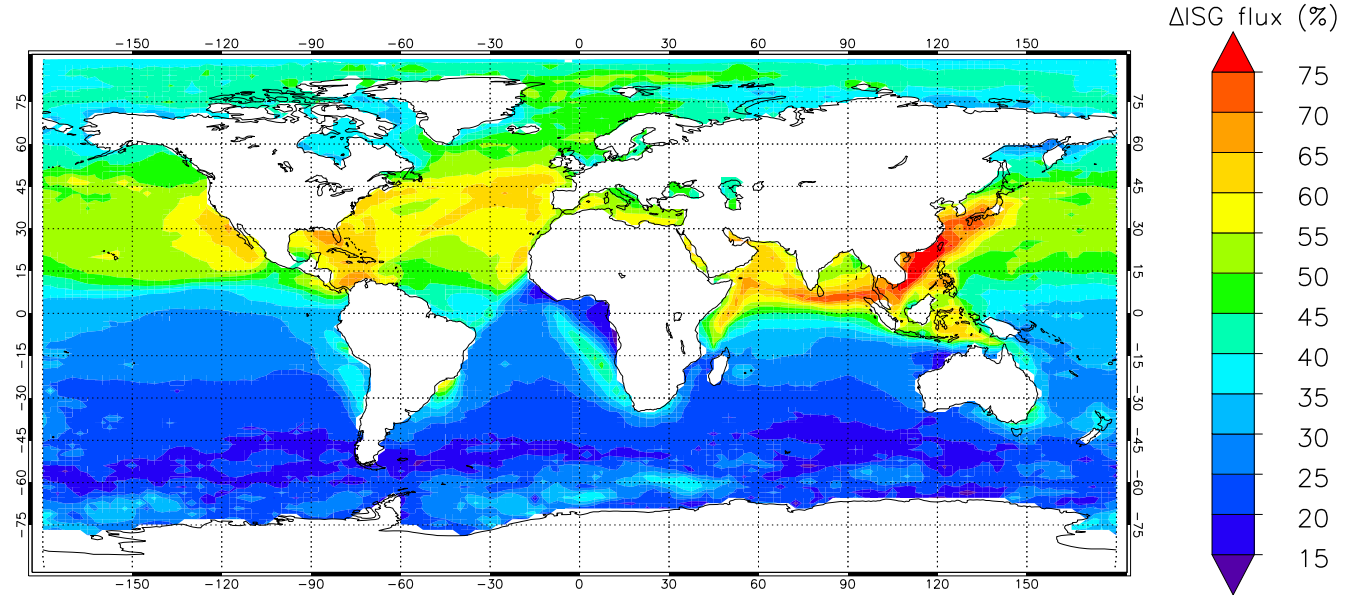

Figure 4. Anthropogenic influence upon the oceanic emission of inorganic iodine. The figure presents the percentage change of the ISG fluxes since pre-industrial times. The annual oceanic flux of ISG for the PD run is shown in Fig. 2.

measured $\left[\mathrm{I}_{\mathrm{aq}}^{-}\right]$and $\mathrm{SST}^{2}$ as compared to the $\operatorname{Ln}\left[\mathrm{I}_{\mathrm{aq}}^{-}\right]$and $\mathrm{SST}^{-1}$ correlation considered by MacDonald et al. (2014) (Eq. 4). Nevertheless, both studies concluded that there was a need for further investigations for a better understanding of processes linked to $\left[\mathrm{I}_{\mathrm{aq}}^{-}\right]$, its global distribution and its parameterisation by means of commonly available marine environment parameters such as SST (other possible proxies are also detailed in the work of Chance et al., 2014). The iodide concentrations modelled herein following Eq. (4), with mean values of $50 \mathrm{nmol} \mathrm{dm}^{-3}$, were in good agreement with the interquartile range of $28-140 \mathrm{nmol} \mathrm{dm}^{-3}$ of the measurements compiled by Chance et al. (2014). As shown in Fig. 1, the modelled latitudinal distribution of $\left[\mathrm{I}_{\mathrm{aq}}^{-}\right]$also reproduced the increasing iodide gradient towards equatorial waters reported by Chance et al. (2014).

Following Eqs. (1)-(3), CAM-Chem computed the ISG flux from the ocean considering the modelled SST (i.e. $\left[\mathrm{I}_{\mathrm{aq}}^{-}\right]$), wind speed and surface ozone concentration for each grid box and time step, resulting on an average iodine emission of $1.9 \mathrm{Tg} \mathrm{yr}^{-1}$ from inorganic precursors (95\% from HOI) as compared to a $0.4 \mathrm{Tg}(\mathrm{I}) \mathrm{yr}^{-1}$ yield from organic sources. The modelled geographical distribution of the ISG fluxes is shown in Fig. 2. Note that, for a given SST, the $\left[\mathrm{I}_{\mathrm{aq}}^{-}\right]$parameterisation according to MacDonald et al. (2014) (i.e. Eq. (4)) results in lower iodide concentrations than considering the above-mentioned $\left[\mathrm{I}_{\mathrm{aq}}^{-}\right]-\mathrm{SST}^{2}$ correlation according to Chance et al. (2014). Also note that the deposition of ozone to the oceans is connected to the ocean biogeochemistry (Ganzeveld et al., 2009). Thus, for instance, if the model considers the electronic affinity between iodide and ozone involved in the deposition process, the consequent emission of iodine to the atmosphere is enhanced particularly in those regions with elevated ozone pollution and high iodide concentrations. Hence the ISG fluxes modelled in this study should be regarded as lower limits.

\subsection{Present-day and pre-industrial simulations}

In order to assess the anthropogenic effect on the natural cycle of iodine in the MBL, two different runs were defined time-wise: present day (PD run) and pre-industrial time (PI run); these are representative of the emissions and resulting atmospheric chemical conditions of 2000 and 1850, respectively (Lamarque et al., 2010; Myhre et al., 2013). To avoid dynamical perturbations and to compare the chemical impacts of different states of the atmosphere, all PD and PI simulations were performed in specified dynamics mode with the same high-frequency meteorological input from a previous CAM-Chem 15-year simulation for the year 2000. Then, the horizontal wind components, air temperature, SST, sensible flux, latent heat flux and wind stress were read from a unique input meteorological data set every 3-6h (Lamarque et al., 2010). The chemical solver was initialised with boundary conditions representative of each of the periods modelled. In particular, $\mathrm{O}_{3}$ initial conditions were taken from previous climatic model simulations with standard tropospheric halogen chemistry, and 2 years of simulations were performed in order to stabilise tropospheric iodine and ozone levels. Prescribed surface concentrations of long-lived halocarbons (CFCs, halons, $\mathrm{CH}_{3} \mathrm{Br}$ and $\mathrm{CH}_{3} \mathrm{Cl}$ ) were also included (Lamarque et al., 2010). Even when all simulations had the same meteorology, the model was allowed to proceed with an independent interannual chemical evolution of all tropospheric constituents, and a direct comparison of the oxidative capacity of different types of atmospheres (PD vs. PI) could be addressed (Lamarque et al., 2012). Note that the organic iodine emissions were considered to remain unaltered in time. Thus, the selection of a set-up with equivalent meteorology for both time periods allowed us to obtain a parameterised ISG flux and resulting total inorganic iodine burden $\left(\mathrm{I}_{\mathrm{y}}=\mathrm{I}+\mathrm{IO}+\mathrm{HOI}+\mathrm{IONO}_{2}+\mathrm{HI}+\mathrm{OIO}+\mathrm{INO}+\mathrm{INO}_{2}+\right.$ 

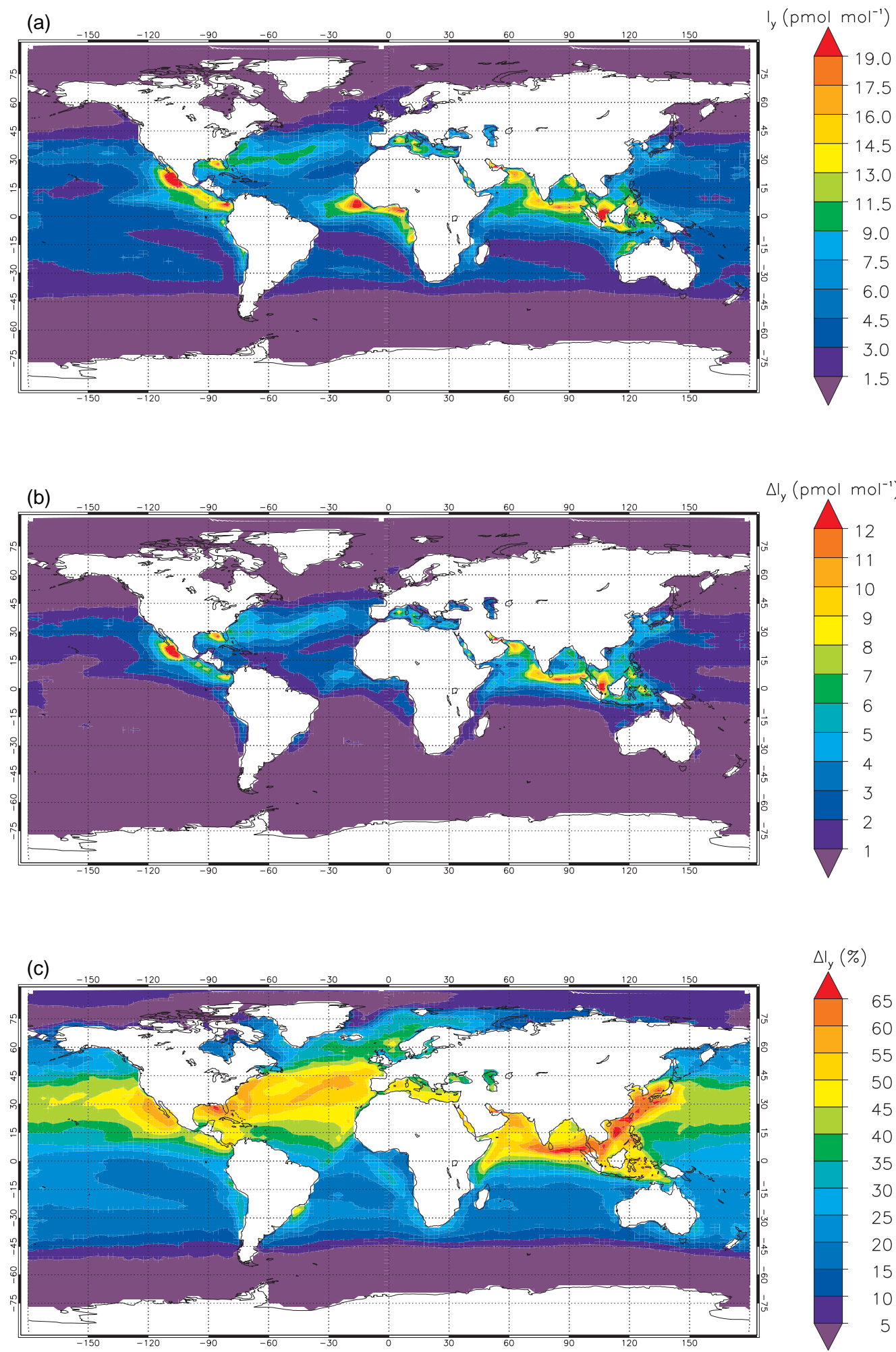

Figure 5. Geographical distribution of the budget of total gaseous inorganic iodine $\left(\mathrm{I}_{\mathrm{y}}=\mathrm{I}+\mathrm{IO}+\mathrm{HOI}+\mathrm{IONO}_{2}+\mathrm{HI}+\mathrm{OIO}+\mathrm{NO}+\mathrm{INO}_{2}+\right.$ $2 \times \mathrm{I}_{2}+\mathrm{IBr}+\mathrm{ICl}+2 \times \mathrm{I}_{2} \mathrm{O}_{\mathrm{x}}$, with $x=2-4$ ) in the MBL: (a) modelled $\mathrm{I}_{\mathrm{y}}$ mixing ratio in the PD scheme; (b) enhancement of the $\mathrm{I}_{\mathrm{y}}$ budget since pre-industrial times (PD-PI); (c) percentage increase in the $\mathrm{I}_{\mathrm{y}}$ budget since industrial revolution, i.e. $100 \times(\mathrm{PD}-\mathrm{PI}) / \mathrm{PD}$. 
$2 \times \mathrm{I}_{2}+\mathrm{IBr}+\mathrm{ICl}+2 \times \mathrm{I}_{2} \mathrm{O}_{\mathrm{x}}$, with $\left.x=2-4\right)$ in the marine environment dependent only on the changes in surface ozone between present and past times. Throughout this study the percentage or relative changes reported were estimated as $100 \times(\mathrm{PD}-\mathrm{PI}) / \mathrm{PD}$.

\section{Results and discussion}

Once the current ISG flux and its global pattern have been determined (Sect. 2.2), we proceed, in the following, to investigate their evolution since 1850 as well as the implications of such an evolution.

\subsection{Change in ozone and atmospheric inorganic iodine since pre-industrial times}

Figure 3 shows the geographical distribution of the modelled present-day ozone burden in the MBL and its change since pre-industrial times (Lamarque et al. 2010). In agreement with observations (Myhre et al., 2013), our simulations indicate that anthropogenic activities since 1850 have caused a mean ozone increase of $40 \%$ in the MBL. As a result of the deposition and subsequent reaction of ozone with iodide in the surface ocean, our results reveal that the human-mediated increase in ozone levels has yielded a rise in the global oceanic ISG flux from $1.04 \mathrm{Tg}$ (I) $\mathrm{yr}^{-1}$ emitted in 1850 to $1.9 \mathrm{Tg}$ (I) $\mathrm{yr}^{-1}$ emitted currently. This ISG flux rise of $45 \%$ (Fig. 4) has caused a similar increase in the total inorganic iodine budget of the global MBL over the last 2 centuries (Fig. 5). Human activities including industrial processes, energy use and agricultural activities have had a more pronounced effect in the Northern Hemisphere where anthropogenic emissions of ozone precursors have dramatically increased since the industrial revolution (Volz and Kley, 1988; Lamarque et al., 2010; Myhre et al., 2013) (Fig. 3b). Consequently, the anthropogenic amplification of the natural oceanic emission of iodine and, therefore, the $\mathrm{I}_{\mathrm{y}}$ abundance in the MBL also reflects a strong northern to southern hemispheric gradient as shown in Fig. 5.

\subsection{Change in iodine-mediated ozone loss rate since pre-industrial times}

Considering all the ozone-depleting families (i.e. odd oxygen, hydrogen, nitrogen, iodine, bromine, chlorine) (Brasseur and Solomon, 2005; see also Saiz-Lopez et al., 2014), we calculate that the industrialisation process has on average increased the rate of the total ozone chemical loss in the global MBL from $1.89 \mathrm{nmol} \mathrm{mol}^{-1} \mathrm{~d}^{-1}$ to $3.19 \mathrm{nmol} \mathrm{mol}^{-1} \mathrm{~d}^{-1}$, mainly driven by changes in the abundance of odd oxygen, hydrogen and iodine. On a global annual average, $25 \%$ of this enhanced ozone loss rate results from the human-driven boosting of inorganic iodine emissions that has accelerated iodine-mediated ozone destruction from $0.54 \mathrm{nmol} \mathrm{mol}^{-1} \mathrm{~d}^{-1}$ in pre-industrial times

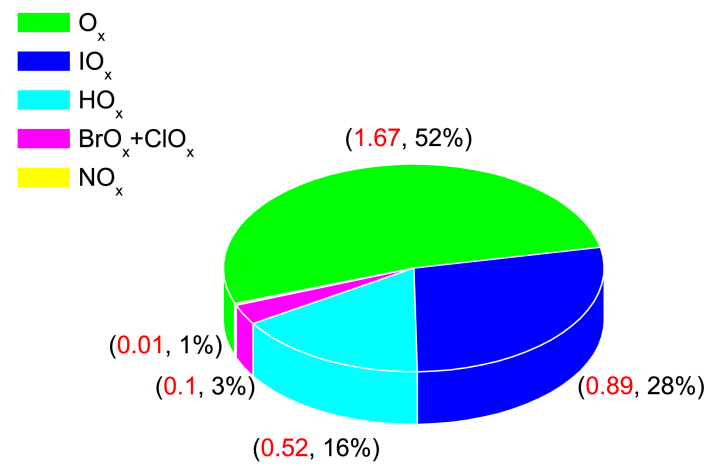

Figure 6. Calculated present-day ozone loss rates by the different chemical families in the MBL (Brasseur and Solomon, 2005). The first number in each set of parentheses (in red) provides the $\mathrm{O}_{3}$ loss rate by the colour-coded family (in nmol mol${ }^{-1} \mathrm{~d}^{-1}$ ). The second value in each set of parentheses provides the relative contribution of each depleting family to the total ozone chemical loss.

to $0.89 \mathrm{nmol} \mathrm{mol}^{-1} \mathrm{~d}^{-1}$ in the present day. Figure 6 depicts the ozone loss rates by the different chemical families in the present-day scheme. As shown in Fig. 7, the ozonedriven increase in iodine emissions since PI times has resulted in a remarkable acceleration of ozone loss in the global MBL with a strong hemispheric gradient. We calculate that since 1850 the total surface $\mathrm{O}_{3}$ loss rate has increased by 2.1 and $0.6 \mathrm{nmol} \mathrm{mol}^{-1} \mathrm{~d}^{-1}$ in the NH (Northern Hemisphere) and SH (Southern Hemisphere), respectively. When only the contribution of the iodine cycle is considered, hemispheric annual changes in the $\mathrm{O}_{3}$ loss rate are 0.5 and $0.2 \mathrm{nmol} \mathrm{mol}^{-1} \mathrm{~d}^{-1}$ in the $\mathrm{NH}$ and $\mathrm{SH}$, respectively (Fig. 7). Notably, iodine was and still is the second strongest ozone-depleting family in the MBL, being responsible for about $30 \%$ of the total ozone loss in that region of the atmosphere (Fig. 6). Integrating the tropospheric column, the rate of iodine-catalysed ozone destruction has increased by $90 \mathrm{Tg} \mathrm{yr}^{-1}$ since the pre-industrialisation era, yielding a total present-day tropospheric-ozone removal by iodine of $280 \mathrm{Tg} \mathrm{yr}^{-1}$.

In general, marine regions surrounding northern developed and developing countries, and areas connecting them, have undergone the strongest amplification of the natural cycle of inorganic iodine emissions as a result of the enhanced deposition of ozone to those regions of the ocean (Figs. 4-7). Remarkably, the current anthropogenic influence maximises in highly polluted coastal regions such as the East and South China seas, the southern Bay of Bengal, the Gulf of Mexico and California's offshore waters (Fig. 3), where we calculate an increase of up to $70 \%$ in atmospheric iodine since PI times (Fig. 5). In these regions of continental ozone-rich outflow the iodine-mediated ozone loss rate in recent times has accelerated by a similar factor, i.e. by about 6 times more (up to $2 \mathrm{nmol} \mathrm{mol}^{-1} \mathrm{~d}^{-1}$ ) than the global average of $0.35 \mathrm{nmol} \mathrm{mol}^{-1} \mathrm{~d}^{-1}$ (Figs. 6, 7). 

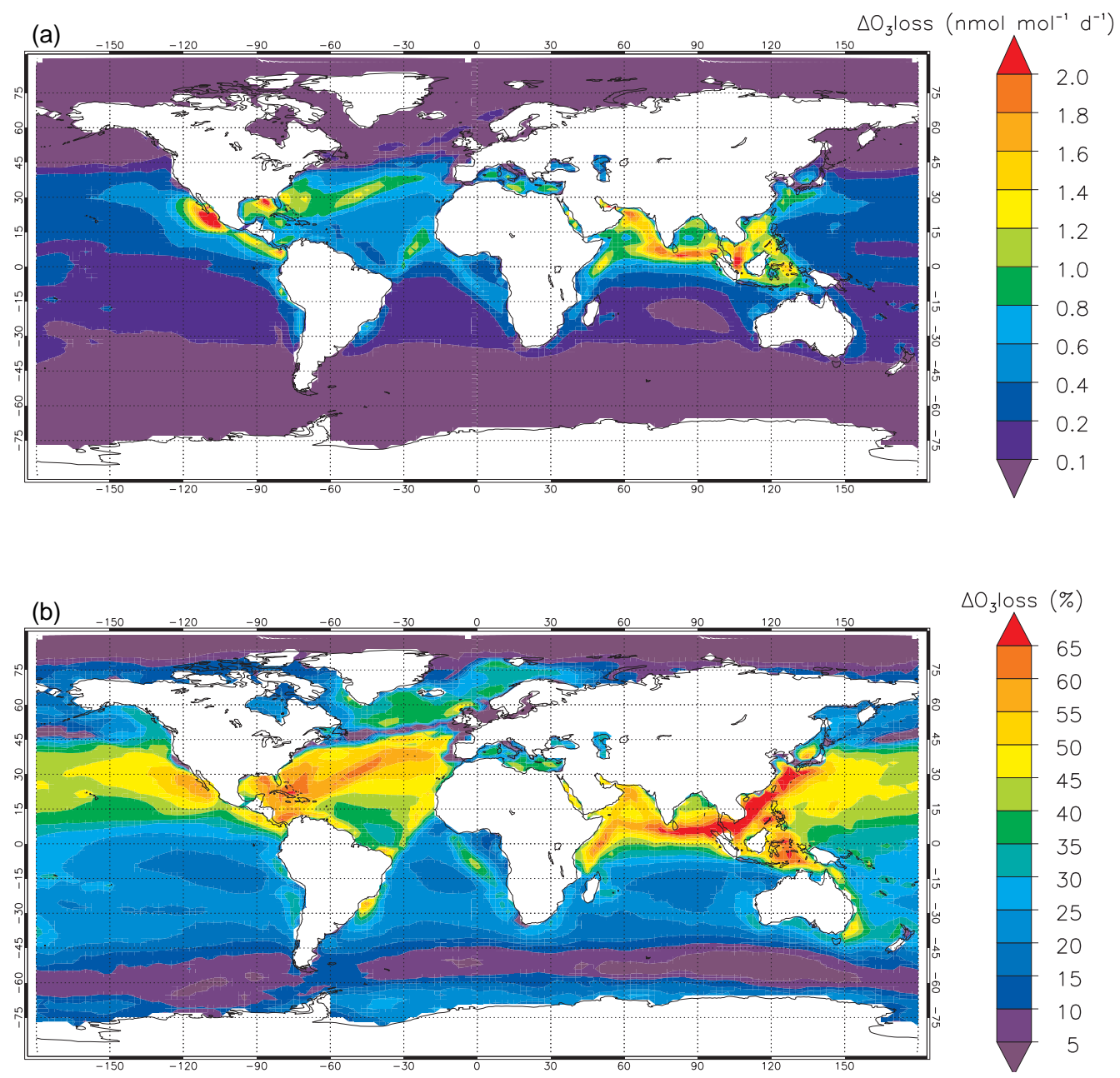

Figure 7. Geographical distribution of the annual acceleration of the ozone chemical loss rate by iodine in the MBL: (a) absolute acceleration (PD-PI); (b) percentage acceleration, i.e. $100 \times(\mathrm{PD}-\mathrm{PI}) / \mathrm{PD}$.

\subsection{Iodine-mediated change in ozone radiative forcing since pre-industrial times}

Due to its long-wave absorption, present-day troposphericozone RF is estimated to be in the range of $0.2-0.6 \mathrm{~W} \mathrm{~m}^{-2}$ (Myhre et al., 2013). Investigating the effect of the ISG flux in the budget of ozone in the tropospheric column and following the methodology of Saiz-Lopez et al. (2012b), we calculate that the tropospheric-ozone depletion caused by current ocean emissions of inorganic iodine reduces the warming effect of ozone in the global marine troposphere by 3-10\% and by up to $20 \%$ on average in the NH. Note, however, that these values should be regarded as lower limits. Based on the recent study by Saiz-Lopez et al. (2014), we investigated the effect that the photolysis of the higher oxides $\mathrm{I}_{2} \mathrm{O}_{\mathrm{x}}(x=2,3$ or 4) - formed after the reactions of IO with itself $(x=2)$, of IO with OIO $(x=3)$ or of OIO with itself $(x=4)$ (Bloss et al., 2001; Spietz et al., 2005; Gómez Martín et al., 2005, 2007; Saiz-Lopez et al., 2008) - could have on the RF of tropospheric ozone. Our results indicate that if the photolysis of $\mathrm{I}_{2} \mathrm{O}_{\mathrm{x}}$ is considered, the current negative effect of the enhanced iodine-mediated ozone loss in the marine troposphere would mitigate the warming long-wave radiative effect of tropospheric ozone by up $20 \%$ globally and by up to $40 \%$ in the NH.

Compared to 1850 , we estimate that the above-mentioned $45 \%$ increase in $\mathrm{I}_{\mathrm{y}}$ loading has yielded a significant decrease in the RF associated with tropospheric ozone, reinforcing the need for a better process-level understanding of the uncertainties in atmospheric iodine chemistry in order to assess the impact of iodine on the tropospheric-ozone RF and its future trends.

\subsection{Geochemical feedback mechanism}

In this study we suggest that the human-driven increase in tropospheric ozone has led to an amplification of the natural cycle of iodine emissions that has consequently decreased 


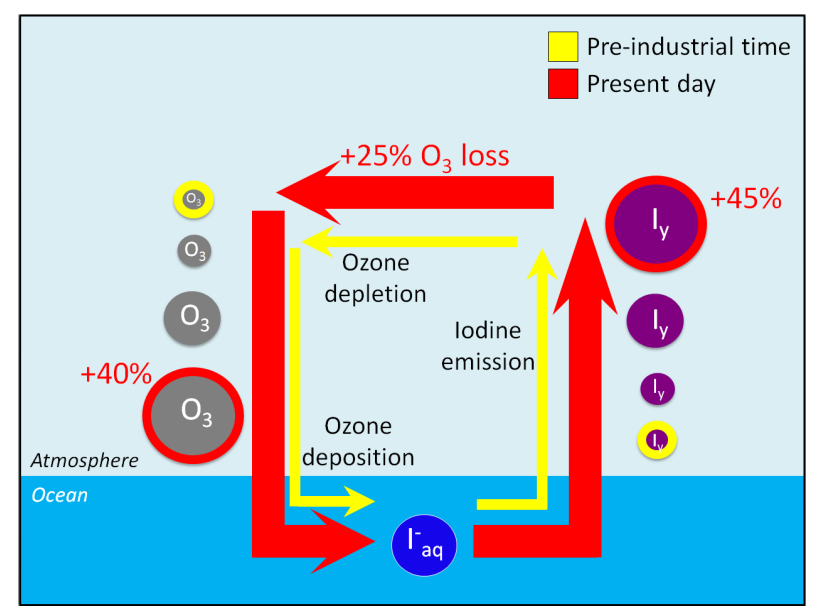

Figure 8. Geochemical feedback mechanism. The anthropogenic increase in tropospheric ozone during the last 2 centuries (20-55\%; Myhre et al., 2013) has led to an amplification of the natural cycle of iodine emissions since pre-industrial times (PI cycle in yellow). This has consequently decreased the lifetime of ozone in the marine atmosphere and of its associated RF, thus closing a negative feedback loop and presenting the ocean emissions of iodine as a natural mitigating factor for anthropogenic RF in the marine environment (PD cycle in red).

the lifetime of ozone in the marine atmosphere, thus closing a negative feedback loop; this concept is illustrated in Fig. 8. The result of this geochemical feedback mechanism indicates that ocean emissions of iodine act as a natural buffer of anthropogenic ozone pollution and its associated RF in the marine troposphere. Despite possible model uncertainties (e.g. in the parameterisation of ISG flux, the dependence of ozone deposition on ocean biogeochemistry or possible changes in climatological parameters since PI times), note that the establishment of this feedback mechanism is inherent to the experimentally proven dependence of inorganic iodine emissions upon the deposition of ozone to the oceans (Garland et al., 1980; Carpenter et al., 2013; MacDonald et al., 2014).

\section{Summary and conclusions}

After investigating past and present interactions of iodine and ozone in the open marine environment, we conclude that the enhanced injection of iodine into the present-day atmosphere, as compared to pre-industrial times, represents a mechanism by which anthropogenic activities have increased the overall reactivity of the atmosphere and have amplified the natural cycle of iodine. The human-mediated boosting of the ISG emissions has, on average, increased the rate of present-day ozone chemical loss in the global marine environment by $25 \%$ compared with the pre-industrial era, with regions where this increase can be up to $70 \%$. The subsequent negative radiative forcing induced by the enhanced iodine-mediated ozone depletion currently mitigates up to
$20-40 \%$ of the effect of tropospheric ozone as a GHG in the Northern Hemisphere. The human-driven enhanced iodine emissions may also have two important additional implications. First, it has likely led to a larger accumulation of the iodine fraction (iodate and iodide) on marine aerosols (Baker, 2004). Second, it may have increased the input of iodine, an essential dietary element for mammals (Whitehead, 1984) that is transported from its oceanic source to the continents.

The negative feedback mechanism described in this work represents a natural buffer of ozone-related pollution and its radiative forcing in the marine environment. This feedback represents a potentially important new link between climate change and tropospheric ozone since the oceanic emissions of iodine are not only linked to surface ozone but also to SST and wind speed (both parameters with a high uncertainty regarding future trends; Rhein et al., 2013), and might also be linked to climatically driven changes in the state of the world's oceans (e.g. upwelling, acidity). All of this highlights the importance of a better understanding of background natural oceanic biogeochemical processes in currently changing environments.

Acknowledgements. This work was supported by the Spanish National Research Council (CSIC). The National Center for Atmospheric Research (NCAR) is funded by the National Science Foundation NSF. The Climate Simulation Laboratory at NCAR's Computational and Information Systems Laboratory (CISL) provided the computing resources (ark:/85065/d7wd3xhc). As part of the CESM project, CAM-Chem is supported by the NSF and the Office of Science (BER) of the US Department of Energy. This work was also sponsored by the NASA Atmospheric Composition Modeling and Analysis Program Activities (ACMAP, number NNX11AH90G). R. P. Fernandez would like to thank ANPCyT (PICT-PRH 2009-0063) for financial support. The supporting data for this article can be requested from the corresponding author A. Saiz-Lopez (a.saiz@csic.es).

Edited by: L. Ganzeveld

\section{References}

Alicke, B., Hebestreit, K., Stutz, J., and Platt, U.: Iodine oxide in the marine boundary layer, Nature, 397, 572-573, 1999.

Baker, A. R.: Inorganic iodine speciation in tropical Atlantic aerosol, Geophys. Res. Lett., 31, L23S02, doi:10.1029/2004GL020144, 2004.

Bloss, W. J., Rowley, D. M., Cox, R. A., and Jones, R. L.: Kinetics and Products of the IO Self-Reaction, J. Phys. Chem. A, 105, 7840-7854, doi:10.1021/jp0044936, 2001.

Brasseur, G. P. and Solomon, S.: Aeronomy of the Middle Atmosphere: Chemistry and Physics of the Stratosphere and Mesosphere, Springer, 2005.

Carpenter, L. J., Archer, S. D., and Beale, R.: Ocean-atmosphere trace gas exchange, Chem. Soc. Rev., 41, 6473-6506, doi:10.1039/C2CS35121H, 2012. 
Carpenter, L. J., MacDonald, S. M., Shaw, M. D., Kumar, R., Saunders, R. W., Parthipan, R., Wilson, J., and Plane, J. M. C.: Atmospheric iodine levels influenced by sea surface emissions of inorganic iodine, Nature Geosci, 6, 108-111, 2013.

Chance, R., Baker, A. R., Carpenter, L., and Jickells, T. D.: The distribution of iodide at the sea surface, Environmental Science: Processes \& Impacts, 16, 1841-1859, doi:10.1039/C4EM00139G, 2014.

Ganzeveld, L., Helmig, D., Fairall, C. W., Hare, J., and Pozzer, A.: Atmosphere-ocean ozone exchange: A global modeling study of biogeochemical, atmospheric, and waterside turbulence dependencies, Global Biogeochem. Cy., 23, GB4021, doi:10.1029/2008GB003301, 2009.

Garland, J. A., Elzerman, A. W., and Penkett, S. A.: The Mechanism for Dry Deposition of Ozone to Seawater Surfaces, J. Geophys. Res., 85, 7488-7492, 1980.

Gómez Martín, J. C., Spietz, P., and Burrows, J. P.: Spectroscopic studies of the $\mathrm{I}_{2} / \mathrm{O}_{3}$ photochemistry: Part 1: Determination of the absolute absorption cross sections of iodine oxides of atmospheric relevance, J. Photochem. Photobiol., A, 176, 15-38, 2005.

Gómez Martín, J. C., Spietz, P., and Burrows, J. P.: Kinetic and Mechanistic Studies of the $\mathrm{I}_{2} / \mathrm{O}_{3}$ Photochemistry, J. Phys. Chem. A, 111, 306-320, 2007.

Gómez Martín, J. C., Mahajan, A. S., Hay, T. D., Prados-Román, C., Ordóñez, C., MacDonald, S. M., Plane, J. M. C., Sorribas, M., Gil, M., Paredes Mora, J. F., Agama Reyes, M. V., Oram, D. E., Leedham, E., and Saiz-Lopez, A.: Iodine chemistry in the eastern Pacific marine boundary layer, J. Geophys. Res.-Atmos., 118, 887-904, doi:10.1002/jgrd.50132, 2013.

Großmann, K., Frieß, U., Peters, E., Wittrock, F., Lampel, J., Yilmaz, S., Tschritter, J., Sommariva, R., von Glasow, R., Quack, B., Krüger, K., Pfeilsticker, K., and Platt, U.: Iodine monoxide in the Western Pacific marine boundary layer, Atmos. Chem. Phys., 13, 3363-3378, doi:10.5194/acp-13-3363-2013, 2013.

Jones, A. E., Anderson, P. S., Wolff, E. W., Roscoe, H. K., Marshall, G. J., Richter, A., Brough, N., and Colwell, S. R.: Vertical structure of Antarctic tropospheric ozone depletion events: characteristics and broader implications, Atmos. Chem. Phys., 10, 7775-7794, doi:10.5194/acp-10-7775-2010, 2010.

Lamarque, J.-F., Bond, T. C., Eyring, V., Granier, C., Heil, A., Klimont, Z., Lee, D., Liousse, C., Mieville, A., Owen, B., Schultz, M. G., Shindell, D., Smith, S. J., Stehfest, E., Van Aardenne, J., Cooper, O. R., Kainuma, M., Mahowald, N., McConnell, J. R., Naik, V., Riahi, K., and van Vuuren, D. P.: Historical (1850-2000) gridded anthropogenic and biomass burning emissions of reactive gases and aerosols: methodology and application, Atmos. Chem. Phys., 10, 7017-7039, doi:10.5194/acp10-7017-2010, 2010.

Lamarque, J. F., Emmons, L. K., Hess, P. G., Kinnison, D. E., Tilmes, S., Vitt, F., Heald, C. L., Holland, E. A., Lauritzen, P. H., Neu, J., Orlando, J. J., Rasch, P. J., and Tyndall, G. K.: CAM-chem: description and evaluation of interactive atmospheric chemistry in the Community Earth System Model, Geosci. Model Dev., 5, 369-411, doi:10.5194/gmd-5-369-2012, 2012.

Lawler, M. J., Mahajan, A. S., Saiz-Lopez, A., and Saltzman, E. S.: Observations of $\mathrm{I}_{2}$ at a remote marine site, Atmos. Chem. Phys., 14, 2669-2678, doi:10.5194/acp-14-2669-2014, 2014.
MacDonald, S. M., Gómez Martín, J. C., Chance, R., Warriner, S. Saiz-Lopez, A., Carpenter, L. J., and Plane, J. M. C.: A laboratory characterisation of inorganic iodine emissions from the sea surface: dependence on oceanic variables and parameterisation for global modelling, Atmos. Chem. Phys., 14, 5841-5852, doi:10.5194/acp-14-5841-2014, 2014.

Mahajan, A. S., Plane, J. M. C., Oetjen, H., Mendes, L., Saunders, R. W., Saiz-Lopez, A., Jones, C. E., Carpenter, L. J., and McFiggans, G. B.: Measurement and modelling of tropospheric reactive halogen species over the tropical Atlantic Ocean, Atmos. Chem. Phys., 10, 4611-4624, doi:10.5194/acp-10-4611-2010, 2010.

Mahajan, A. S., Gómez Martín, J. C., Hay, T. D., Royer, S.-J., Yvon-Lewis, S., Liu, Y., Hu, L., Prados-Roman, C., Ordóñez, C., Plane, J. M. C., and Saiz-Lopez, A.: Latitudinal distribution of reactive iodine in the Eastern Pacific and its link to open ocean sources, Atmos. Chem. Phys., 12, 11609-11617, doi:10.5194/acp-12-11609-2012, 2012.

Myhre, G. D., Shindell, D., Bréon, F.-M., Collins, W., Fuglestvedt, J., Huang, J., Koch, D., Lamarque, J.-F., Lee, D., Mendoza, B., Nakajima, T., Robock, A., Stephens, G., Takemura, T., and Zhang, H.: Anthropogenic and Natural Radiative Forcing, in: Climate Change 2013: The Physical Science Basis. Contribution of Working Group I to the Fifth Assessment Report of the Intergovernmental Panel on Climate Change, edited by: Stocker, T. F., Qin, D., Plattner, G.-K., Tignor, M., Allen, S. K., Boschung, J., Nauels, A., Xia, Y., Bex, V., and Midgley, P. M., Cambridge University Press, Cambridge, United Kingdom and New York, NY, USA, Chap. 8, 2013.

Ordóñez, C., Lamarque, J.-F., Tilmes, S., Kinnison, D. E., Atlas, E. L., Blake, D. R., Sousa Santos, G., Brasseur, G., and Saiz-Lopez, A.: Bromine and iodine chemistry in a global chemistry-climate model: description and evaluation of very short-lived oceanic sources, Atmos. Chem. Phys., 12, 1423-1447, doi:10.5194/acp12-1423-2012, 2012.

Rayner, N. A., Parker, D. E., Horton, E. B., Folland, C. K., Alexander, L. V., Rowell, D. P., Kent, E. C., and Kaplan, A.: Global analyses of sea surface temperature, sea ice, and night marine air temperature since the late nineteenth century, J. Geophys. Res.Atmos., 108, 4407, doi:10.1029/2002JD002670, 2003.

Read, K. A., Mahajan, A. S., Carpenter, L. J., Evans, M. J., Faria, B. V. E., Heard, D. E., Hopkins, J. R., Lee, J. D., Moller, S. J., Lewis, A. C., Mendes, L., McQuaid, J. B., Oetjen, H., Saiz-Lopez, A., Pilling, M. J., and Plane, J. M. C.: Extensive halogen-mediated ozone destruction over the tropical Atlantic Ocean, Nature, 453, 1232-1235, 2008.

Rhein, M., Rintoul, S. R., Aoki, S., Campos, E., Chambers, D., Feely, R. A., Gulev, S., Johnson, G. C., Josey, S. A., Kostianoy, A., Mauritzen, C., Roemmich, D., Talley, L. D., and Wang, F.: Observations: Ocean, in: Climate Change 2013: The Physical Science Basis. Contribution of Working Group I to the Fifth Assessment Report of the Intergovernmental Panel on Climate Change, edited by: Stocker, T. F., Qin, D., Plattner, G.-K., Tignor, M., Allen, S. K., Boschung, J., Nauels, A., Xia, Y., Bex, V., and Midgley, P. M.. Cambridge University Press, Cambridge, United Kingdom and New York, NY, USA. Chap. 3, 2013.

Saiz-Lopez, A., Plane, J. M. C., Mahajan, A. S., Anderson, P. S., Bauguitte, S. J.-B., Jones, A. E., Roscoe, H. K., Salmon, R. A., Bloss, W. J., Lee, J. D., and Heard, D. E.: On the vertical distribution of boundary layer halogens over coastal Antarctica: im- 
plications for $\mathrm{O}_{3}, \mathrm{HO}_{\mathrm{x}}, \mathrm{NO}_{\mathrm{x}}$ and the $\mathrm{Hg}$ lifetime, Atmos. Chem. Phys., 8, 887-900, doi:10.5194/acp-8-887-2008, 2008.

Saiz-Lopez, A., Plane, J. M. C., Baker, A. R., Carpenter, L. J., Von Glasow, R., Gómez Martín, J. C., McFiggans, G., and Saunders, R. W.: Atmospheric Chemistry of Iodine, Chem. Rev. (Washington, DC, US), 112, 1773-1804, doi:10.1021/cr200029u, 2012a.

Saiz-Lopez, A., Lamarque, J.-F., Kinnison, D. E., Tilmes, S., Ordóñez, C., Orlando, J. J., Conley, A. J., Plane, J. M. C., Mahajan, A. S., Sousa Santos, G., Atlas, E. L., Blake, D. R., Sander, S. P., Schauffler, S., Thompson, A. M., and Brasseur, G.: Estimating the climate significance of halogen-driven ozone loss in the tropical marine troposphere, Atmos. Chem. Phys., 12, 3939-3949, doi:10.5194/acp-12-3939-2012, 2012 b.

Saiz-Lopez, A., Fernandez, R. P., Ordóñez, C., Kinnison, D. E., Gómez Martín, J. C., Lamarque, J.-F., and Tilmes, S.: Iodine chemistry in the troposphere and its effect on ozone, Atmos. Chem. Phys., 14, 13119-13143, doi:10.5194/acp-14-131192014, 2014.
Spietz, P., Gómez Martín, J. C., and Burrows, J. P.: Spectroscopic studies of the $\mathrm{I}_{2} / \mathrm{O}_{3}$ photochemistry: Part 2 . Improved spectra of iodine oxides and analysis of the IO absorption spectrum, J. Photochem. Photobiol., A, 176, 50-67, 2005.

Volz, A. and Kley, D.: Evaluation of the Montsouris series of ozone measurements made in the nineteenth century, Nature, 332, 240242, 1988.

Whitehead, D. C.: The distribution and transformations of iodine in the environment, Environ. Intern., 10, 321-339, doi:10.1016/0160-4120(84)90139-9, 1984. 